\title{
Observation: Long-term increases in mesquite canopy cover in a North Texas savanna
}

\author{
R. JAMES ANSLEY, X. BEN WU, AND BETTY A. KRAMP
}

Authors are Associate Professor, Texas Agricultural Experiment Station, Vernon, Texas 76384, Assistant Professor, Department of Rangeland Ecology and Management, Texas A\&M University, College Station, Tex. 77843-2621, and Research Associate, Texas Agricultural Experiment Station, Vernon, Tex. 76384.

\begin{abstract}
It is necessary to quantify rates of woody plant encroachment on southwestern USA rangelands to determine the economic feasibility of treatments designed to manage these plants. This study observed changes in honey mesquite (Prosopis glandulosa Torr.) canopy cover over a 20-year period (1976-1995) in 2 treatments: an untreated area that initially had a moderately dense mesquite stand $(14.6 \%$ cover), and an area cleared of mesquite with rootplowing in 1974. Canopy cover of mesquite was estimated from scanned color-infrared aerial photograph images by manually delineating mesquite canopies with a computer using ArcView software. During the 20 years, mesquite cover in the untreated area increased $(P \leq 0.05)$ from 14.6 to $58.7 \%$, averaging 2.2 percentage units per year. Cover in the root-plow treatment also significantly increased during the same period from 0 to $21.9 \%(1.1$ percentage units per year), but the rate of increase was significantly lower than in the untreated area because mesquite growth was from new seedlings instead of established plants and/or new seedlings as occurred in the untreated area. Rate of increase was significantly lower from 1976 to 1990 (1.6 and 0.2 percentage units per year) than from 1990 to 1995 (4.1 and 3.7 percentage units per year) in the untreated and root-plow treatment, respectively. These differences were attributed to precipitation which was near normal from 1976 to 1990 but $25 \%$ above normal from 1991 to 1995.
\end{abstract}

Key Words: honey mesquite, Prosopis, density, shrub encroachment, aerial photography, image analysis

It is necessary to quantify long-term rates of woody plant encroachment on southwestern United States rangelands to determine the economic feasibility of treatments designed to manage such plants. Long-term changes in cover and density of the arborescent legume, honey mesquite (Prosopis glandulosa Torr.), on specific sites and soil types are not well quantified (Grover and Musick 1990). Much of the information includes either nonquantitative photographic comparisons (Hastings and Turner 1965, Martin and Turner 1977), summaries of areas either occu-

This project was supported by a grant from the E. Paul and Helen Buck Waggoner Foundation, Vernon, Tex., and the University of Texas-Surface Leasing (UT-Lands), Midland, Texas. The W.T. Waggoner Estate, Vernon, Texas provided the land area for the research. Dick Richardson, Pat Behrens, Pete Jacoby, and Xiaolian Ren assisted with aerial photography acquisition and processing. Authors wish to thank Darrell Ueckert, Richard Teague, Mort Kothmann and 4 anonymous reviewers for review comments. Spanish translation by Maria Andrea Lu Tomas De Pisani.

Manuscript accepted 22 May 2000.

\section{Resumen}

Cuantificar la tasa de incremento de plantas leñosas en la región del sudoeste de USA es necesario para determinar la factibilidad económica de los tratamientos diseñados para el manejo de estas plantas. En este estudio se observaron cambios en la cobertura de la canopia de mesquite (Prosopis glandulosa Torr.) en un período de 20 años (1976-1995) en dos tratamientos: un área no tratada con una cobertura inicial moderadamente densa de mesquite $(14.6 \%)$, y un área tratada que fue desmontada en 1974 sacando el mesquite desde la raíz. La cobertura de la canopia del mesquite fue estimada a partir de fotografías aéreas digitalizadas color-infrarrojas en las que la canopia se delineó con una computadora que utiliza el programa ArcView. La cobertura de mesquite en el área no tratada se incrementó $(P \leq 0.05)$ de 14.6 a $58.7 \%$ después de 20 años, con un promedio de 2.2 unidades porcentuales por año. La cobertura en el área tratada también sufrió un incremento significativo desde 0 a $21.9 \%$ en el mismo período (1.1 unidades porcentuales por año). Sin embargo, la tasa de incremento fue significativamente menor que en el área no tratada debido a que el crecimiento del mesquite fue a partir de nuevas plántulas y no de plantas ya establecidas y / o de nuevas plántulas como ocurrió en el área no tratada. La tasa de incremento fue significativamente menor entre 1976 y 1990 (1.6 y 0.2 unidades porcentuales por año) que entre 1990 y 1995 (4.1 y 3.7 unidades porcentuales por año) en las áreas no tratadas y tratadas respectivamente. Las diferencias fueron atribuidas a la precipitación, ya que fue cercana a lo normal desde 1976 a 1990 aunque 25\% por encima de lo normal desde 1991 a 1995.

pied (at any cover or density) or not occupied by mesquite (Buffington and Herbel 1965), or surveys in which mesquite stands are placed into generalized cover classes (e.g., 1-10\%) (Smith and Rechenthin 1964, Garrison and McDaniel 1982). Some studies have quantified changes in mesquite cover for specific sites (Parker and Martin 1952, Archer et al. 1988, Warren et al. 1996). However, few data are available for honey mesquite in north Texas or southern Oklahoma, which represent the northern extent of the mesquite distribution range (Fisher et al. 1959, Jacoby and Ansley 1991).

Our objective was to quantify the rate at which honey mesquite increased in canopy cover on a moderately productive clay loam site over a 20-year period (1976 to 1995) using aerial photography. Comparisons were made between a root-plow treatment, which killed over $95 \%$ of mesquite and eliminated all mesquite cover, and an adjacent untreated area that initially had a moderately dense stand of mesquite. 


\section{Materials and Methods}

Research was conducted on a clay loam site in north Texas, south of Vernon $\left(33^{\circ}\right.$ $51^{\prime} \mathrm{N}, 99^{\circ} 26^{\prime} \mathrm{W}$; elevation $381 \mathrm{~m}$ ). Mean annual rainfall is $66.5 \mathrm{~cm}$. Soils were level and uniform throughout the study area, consisting of fine, mixed, thermic Typic Paleustolls of the Tillman series which are alluvial clay loams 3-4 m deep, underlain by Permian sandstone/shale parent material (Koos et al. 1962). Vegetation was a mixture of native grasses and a mesquite overstory. Lotebush [Ziziphus obtusifolia (T.\&G.) Gray] comprised less than $2 \%$ of the woody species composition. Dominant perennial grasses included Texas wintergrass (Nasella leucotricha [Trin. And Rupr.] Pohl.) and buffalograss (Buchloe dactyloides) [Nutt.] Englem.).

Changes in mesquite cover were measured on 2 adjacent 3.6 ha $(120 \mathrm{~m} \mathrm{x} 300$ $\mathrm{m})$ areas which received different treatments: (1) untreated, and (2) root-plowed in 1974 that killed over $95 \%$ of mesquite and reduced mesquite cover to zero. The root-plowed area was seeded to sideoats grama [Bouteloua curtipendula (Michx.) Torr.] in 1974. Root-plowing followed by seeding were assumed to be 2 phases of the same treatment and are referred to as "root-plow treatment" for the remainder of the paper. Following moderate continuous grazing for at least 50 years, livestock (cattle) grazing was removed from both treatment areas in 1988 (as part of another study).

Both treatment areas were aerial-photographed using color-infrared film in 1976, 1990, and 1995 at low altitude (1:3000 nominal resolution). These photographs were scanned with an approximate $0.1-\mathrm{m}$ resolution using a Microtek Scanmaker E6. Scanned images were georeferenced, using ground control points collected with a GPS unit. Within each treatment, six, 0.2 ha $(40 \mathrm{~m}$ by $50 \mathrm{~m})$ areas were selected as replicate subsamples along a fixed grid pattern. All 12 subsamples were within $300 \mathrm{~m}$ of each other. Mesquite canopies were delineated within each replicate by manually digitizing a line around each canopy on the screen using ArcView GIS (ESRI 1998a). Mesquite canopy cover is synonymous with "aerial crown cover", and represents the percentage of land surface area occupied by mesquite canopies as viewed from above.

The 1976 images, taken in June, had high contrast between mesquite canopies and grass areas. The 1990 and 1995 images were taken in October of each year and contained considerable shading by canopies which extended into the interstitial spaces between canopies of neighboring trees. Using the digitizing method, we were able to visually exclude most shaded grass areas in the 1990 and 1995 images. About 40 hours were required to hand-digitize mesquite canopies on the 36 plot images (12 per year x 3 sample years; although the root-plow treatment in 1976 had no visible mesquite).

Mesquite cover estimates from the 1990 aerial photographs were compared to line transects performed on the site at the end of the 1991 growing season. In each treatment area, three, 60-meter line transects were established in a fixed grid pattern and mesquite cover was determined using the line intercept method (Cook and Stubbendieck 1986). Additional measurements included mesquite density, determined using the point-centered quarter method, mesquite height, and canopy diameter. Herbaceous composition by percent canopy cover was determined along the same transect lines in October 1994 using a variation of methods outlined by Daubenmire (1959). A $0.25 \mathrm{~m}^{2}$ frame was placed at each point on the line, and canopy cover of each species as a percent of total ground area within the frame was visually estimated.

Results of digitizing were converted to ArcView Spatial Analyst (ESRI 1998b) grid themes (raster format) with $0.1-\mathrm{m}$ resolution. A landscape analysis software program, FRAGSTATS (McGarigal and Marks 1995), was used to quantify the spatial attributes and temporal dynamics of mesquite canopy patches in the plots (Gustafson 1998, Wu et al. 2000). In addition to the percent cover of mesquite in each plot, the patch density, mean patch size, mean nearest neighbor distance, and mean shape index for the mesquite patches in each plot were determined. A mesquite patch was defined as a discrete area of mesquite canopy consisting of 1 or more individuals with visually connected canopies. Patch density was defined as the number of discrete mesquite areas per ha; mean patch size was the average area of the patches $\left(\mathrm{m}^{2}\right)$; and the mean nearest neighbor distance was the average edge-to-edge distance $(\mathrm{m})$ from each patch to its closest neighbor. The mean patch shape index was used to quantify the average shape complexity of the patches in a plot. The shape index of a mesquite patch is defined as $0.25^{*} \mathrm{P} / \mathrm{A}^{1 / 2}$, where $\mathrm{P}$ is the perimeter and $\mathrm{A}$ is the area of the patch (McGarigal and Marks 1995). The shape index equals one for a patch with the simplest raster shape, a square, and increases when the shape of a patch becomes more complex.
The rate of change in percent cover from an earlier year to a later year was determined by subtracting the cover value of the earlier year from that of the later year and dividing this amount by the number of growing seasons between the 2 dates. Annual change was expressed as a "percentage unit" per year when calculated in this manner. The year 1976 was included in rate of change calculations because the photographs were taken at the beginning of the growing season. The years 1990 and 1995 were included in the rate calculations because photographs were taken at the end of each of these growing seasons. Total growing seasons from 1976 to 1995 were 20.

Because the experimental units were not true replicates, $\mathrm{t}$-tests were used to compare the untreated vs. root-plow treatments within each sample year, rate of increase within each treatment, and rate of increase between treatments. All inferences regarding comparisons between treatments were made from individual plots which represent a specific plant community.

\section{Results and Discussion}

During the 20-year period from 1976 to 1995, 11 years had above average precipitation and 9 were below average (Fig. 1). Average annual precipitation for all 20 years was $70.3 \mathrm{~cm}$, or $5.7 \%$ above normal. Average annual precipitation from 1976 to 1990 was nearly normal at $65.9 \mathrm{~cm}$ per year. An extended drought from 1977 to 1981 and record high temperatures in 1980 killed large areas of buffalograss, one of the hardiest grasses in the region (Heitschmidt and Schultz 1985). Annual precipitation from 1991 to 1995 was $25.4 \%$ above normal, averaging $83.4 \mathrm{~cm}$ per year.

Mesquite canopy cover in the untreated area increased $(\mathrm{P} \leq 0.05)$ from 14.6 to $58.7 \%$ during the 20 -year period, an average of 2.2 percentage units per year (Fig. 2). Cover in the root-plow treatment also increased during the same period from 0 to $21.9 \%$, but the rate of increase (1.1 percentage units per year) was significantly lower than in the untreated area. The slower rate in the root-plow treatment was due to mesquite growth only from new seedlings instead of growth from established root systems and/or new seedlings (Hamilton et al. 1981). Cover in the rootplow treatment in 1995 (21.9\%) was similar to that in the untreated area in 1976 (14.6\%). 


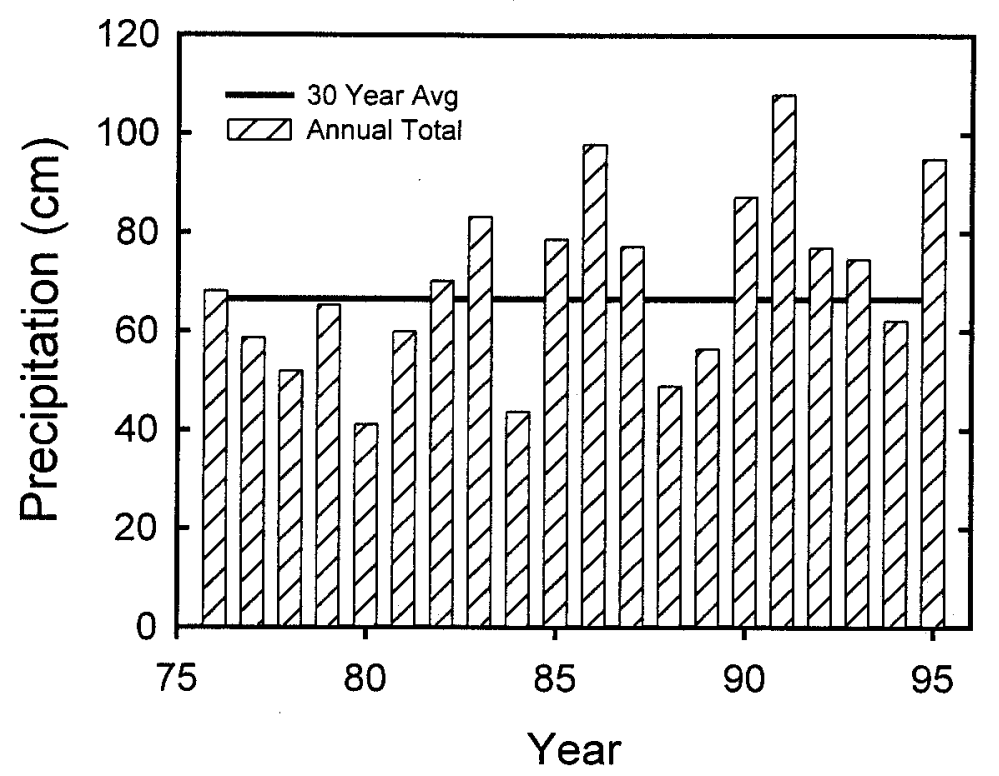

Fig. 1. Annual precipitation at the research site south of Vernon, Texas from 1976 to 1995 compared to the 30-year average.

Rate of increase in both the untreated and root-plow treatments was much lower from 1976 to 1990 (1.6 and 0.2 percentage units per year, respectively) than from 1990 to 1995 (4.1 and 3.7 percentage units per year, respectively). Cover in the rootplow treatment increased at a faster rate from 1990 to 1995 (3.7 percentage units per year) than it did in the untreated area from 1976 to 1990 (1.6 percentage units per year), even though initial cover was less in the root-plow treatment $(3.4 \%$ in 1990) than it was in the untreated area (14.6\% in 1976). This suggests that precipitation had a greater influence on rate of cover increase than did the initial level of canopy cover. It should also be noted that, relative to the 1990 value of $3.4 \%$, mesquite cover in the root-plow treatment increased over 500\% from 1990 to 1995 (from 3.4 to $21.9 \%$ ).

Line transect data indicated that mesquite cover in 1991 was 41.9 (S.E. 8.8) and 14.1 (S.E. 2.8) \% in the untreated and root-plow areas, respectively (Fig. 2). In both treatments, the 1991 line transect cover values were greater than that determined from the 1990 aerial images (41.9 vs 38.0 and 14.1 vs. $3.4 \%$ in untreated and root-plow treatments, respectively). In the untreated area, if we assume an annual increase in cover of about $2.2 \%$, the 1990 line transect cover value was projected to be $39.7 \%$, which was very similar to the aerial image estimate of $38 \%$. The larger difference between the line transect and aerial image estimates of cover in the rootplow treatment may indicate that the aerial mesquite height was 3.1 and $1.6 \mathrm{~m}$ and canopy diameter was 3.3 and $1.8 \mathrm{~m}$ in the untreated and root-plow areas, respectively.

Herbaceous composition by percent cover differed in the 2 treatments due to seeding after root-plowing. In 1994, dominant species in the untreated area were Japanese brome (Bromus japonicus Thunb. Ex Murray) (47\%), buffalograss (20\%) and Texas wintergrass (17\%). Dominant species in the root-plow treatment were Texas wintergrass $(58 \%)$, sideoats grama $(21 \%)$ and Japanese brome (17\%).

\section{Spatial Attributes and Dynamics}

In addition to the changes in canopy cover, there had been complex changes in the spatial attributes of mesquite patches which provided additional insights into the dynamics of the systems. Changes in mesquite patch density can be influenced by 3 processes: recruitment of new mesquite plants or patches, coalescing of expanding mesquite patches, and mortality of mesquite trees. In the untreated area, patch density remained unchanged from 1976 to 1990 and then sharply declined from 1990 to 1995 (Fig. 3a). Recruitment of new patches and coalescing of existing patches balanced each other from 1976 to 1990, resulting in stable patch density. The sharp decrease in patch density from 1990 to 1995 indicated considerable coalescing (and possibly decreased recruitment with space and resources becoming more limiting). In the root-plow treatment,

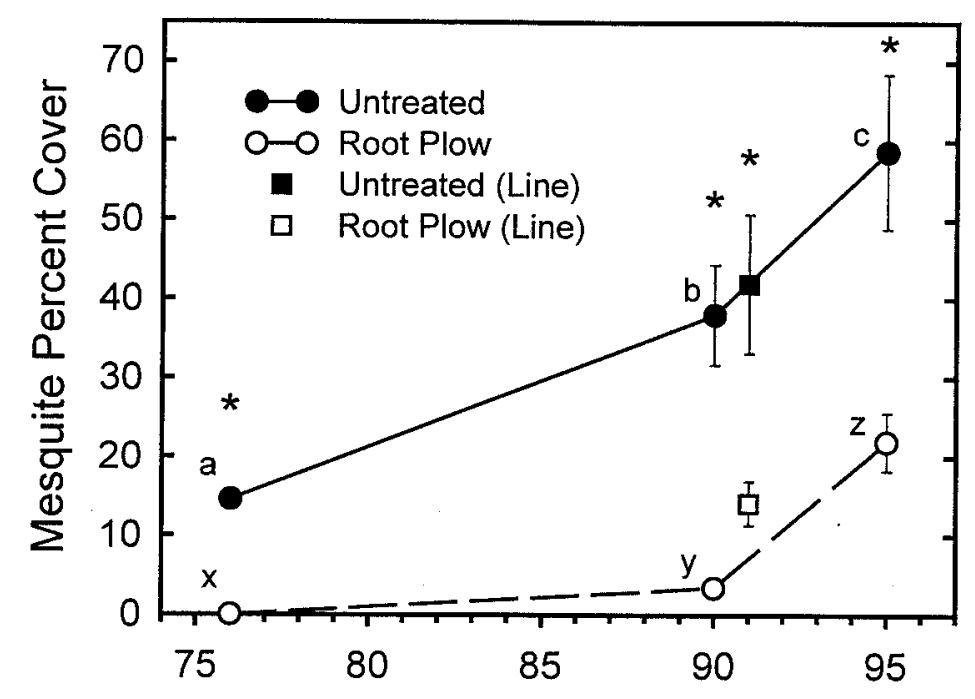

Fig. 2. Mesquite canopy cover in untreated and root-plow treatments near Vernon, Tex. from 1976 to 1995 . Circles are aerial image estimates $(n=6)$ and squares are line transect data $(n=3)$. Vertical lines indicate \pm 1 standard error of the mean. Different lower case letters indicate significant difference $(p<0.05)$ within a treatment based on t-tests. An asterisk indicates significant difference $(p<0.05)$ between treatments on a given date. 

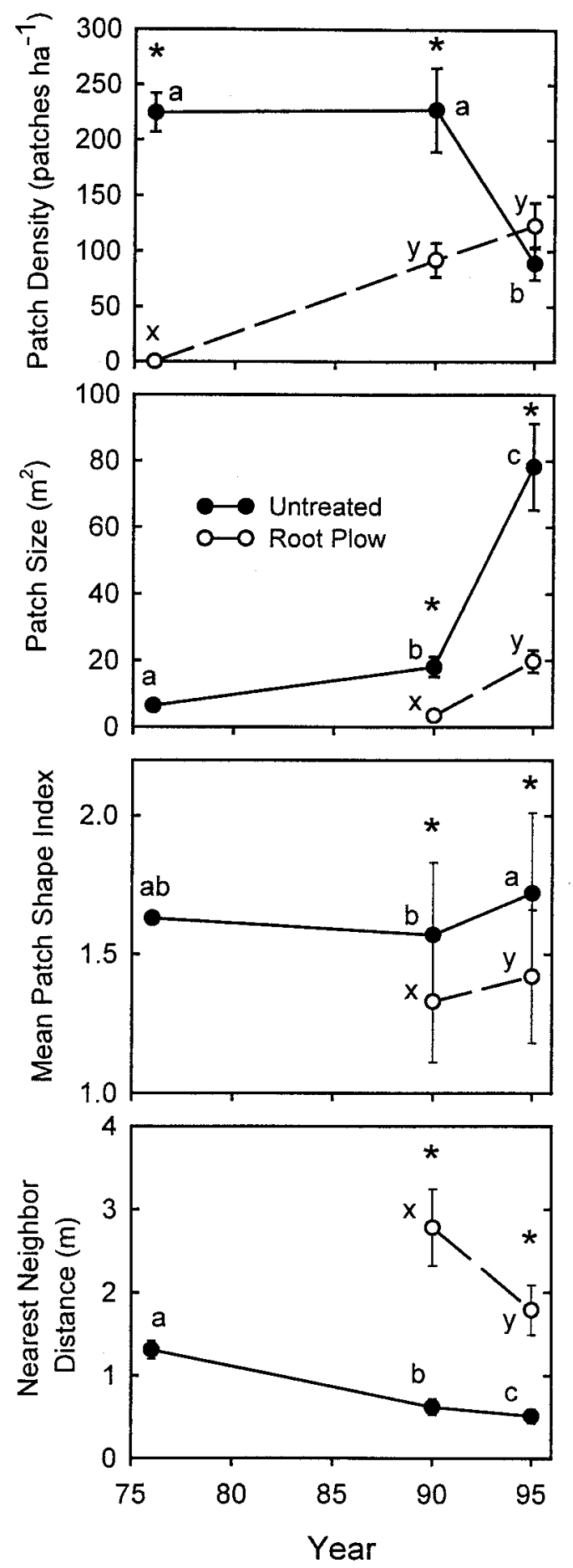

Fig. 3. Spatial attributes of mesquite patches (patch density, mean patch size, mean patch shape index and mean nearest neighbor distance) in untreated and root-plow areas near Vernon, Tex. from 1976 to 1995 . Vertical lines indicate \pm 1 standard error. Different lower case letters indicate significant difference $(p<0.05)$ within a treatment based on t-tests. An asterisk indicates significant difference $(p<0.05)$ between treatments on a given date.

patch density increased from 1976 to 1995 at a consistent rate. There appeared to be continuous recruitment but little or no coalescing in this period.

Mean patch size in the untreated area gradually increased from 1976 to 1990 , followed by a sharp increase from 1990 to 1995 (Fig. 3b). No mortality of adult mesquite was observed at the study site from 1976 to 1995 . Patch size increased at a slower rate in the root-plow treatment from 1990 to 1995 . The mean patch shape index for the untreated area was similar between 1976 and 1990, then increased significantly from 1990 to 1995 (Fig. 3c). This indicated there was little coalescing or recruitment of new mesquite from 1976 to 1990 , because either coalescing (increased shape complexity) or recruitment (more small patches) would change the shape index. Coalescing of expanding mesquite patches from 1990 to 1995 increased the shape index. The shape index was less in the root-plow treatment than in the untreated area in both 1990 and 1995, but increased from 1990 to 1995 due to recruitment (i.e., more small patches).

The nearest neighbor distance in the untreated area decreased from 1976 to 1990 as the mesquite patches grew larger, and the rate of decrease was reduced from 1990 to 1995 by the large amount of coalescing (elimination of many narrow gaps between patches) with little recruitment (Fig. 3d). The greater decline in nearest neighbor distance for the root-plow treatment from 1990 to 1995 suggests a much higher rate of recruitment with lower mesquite cover when compared to the untreated area with higher cover. Change in mesquite cover in 1 of the untreated area replicates is illustrated in Fig. 4. Expansion and coalescing of canopies can be readily observed.

\section{Ecological and Management Implications}

Historical accounts differ as to original density and distribution of honey mesquite in north Texas, but observational records indicate the species was present prior to European settlement and, in some instances, occurred as dense stands (Bartlett 1854, Marcy 1866). Increases in mesquite density and distribution during the last century are usually attributed to rangeland management practices which suppressed naturally occurring fires, enhanced seed distribution, and reduced grass competition from livestock grazing (Humphrey 1949, Parker and Martin 1952, Archer 1989, Kramp et al. 1998). Climatic changes and increasing atmospheric carbon dioxide have also been identified as possible reasons for mesquite encroachment (Polley et al. 1994, Archer et al. 1995). Efforts to control mesquite in the last 50 years involved repeated use of chemical or mechanical treatments which often resulted in aboveground mortality (top-kill) but limited whole plant mortality (root-kill) (Jacoby and Ansley 1991). These treatments accelerated increases in mesquite cover because they served to stimulate regrowth from stem bases and an increased number of stems per plant and per land area. 

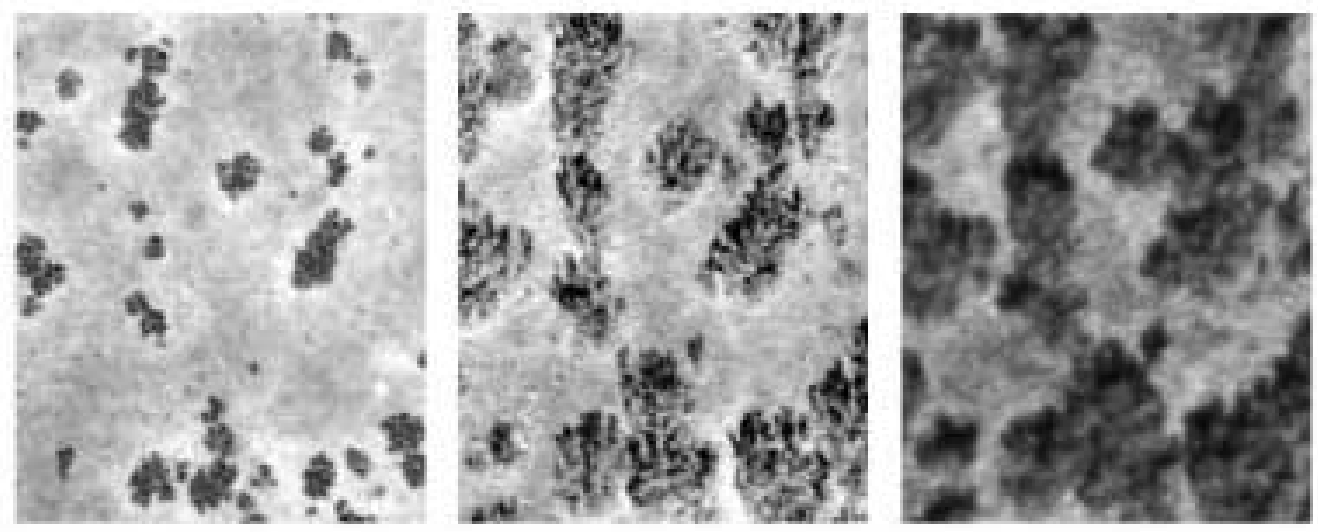

Fig. 4. View of mesquite cover in 1 replicate $(40 \times 50 \mathrm{~m}$ in size) of the untreated area in 1976 (left), 1990 (middle), and 1995 (right). Dark areas on 1990 and 1995 panels indicate shade cast by mesquite canopies. Cover estimates are 11.8, 37.8 and 54.2\% in 1976, 1990, and 1995 respectively.

Few studies have examined changes in mesquite cover on specific land areas over time. Usually mesquite encroachment is expressed in terms of changes in distribution (i.e., total area occupied by mesquite), or as a combined distribution/cover index by identifying land areas that have a range of mesquite aerial cover such as $1-10 \%$, $10-20 \%$, and $>20 \%$ (Garrison and McDaniel 1982, Smith and Rechenthin 1964). For example, Buffington and Herbel (1965) found, on the Jornada Experimental Range in New Mexico, that mesquite-infested areas increased from 11,636 to 36,680 ha from 1858 to 1963 , but no data were available on the actual quantitative changes in cover on specific sites. Surveys by the Soil Conservation Service indicated that from 1963 to 1982 , the total land area in Texas occupied by mesquite decreased from 22.5 to 20.5 million ha, and areas that had $>10 \%$ canopy cover decreased from 13.6 to 7.6 million ha (Smith and Rechenthin 1964, SCS 1988). These decreases were probably the result of brush control efforts (Scifres 1980), but no data were available that monitored cover on specific sites through time. Most aerial photographs available from 1940-1980 were taken in winter months when cover of a deciduous plant such as mesquite cannot be clearly delineated. Thus, data which quantifies mesquite cover changes over time are rare.

Of the few long-term studies monitoring mesquite cover on specific sites, rates of increase indicate a range of 0.2 to 1.2 percentage units per year. In south Texas, Archer et al. (1988) determined that mixed brush cover (including mesquite) on two south Texas sites increased from 14 to $23 \%$ and 8 to $36 \%$, respectively over 23 years (1960-1983), or 0.4 and 1.2 percent- age units per year. However, from 1941 to 1960 , a period marked by extreme droughts, cover increased by only $1 \%$ on one site (13 to $14 \%)$ and declined on the other (13 to $8 \%$ ). Thus, over a 42 -year span (1941 to 1983) cover increases averaged 0.2 and 0.5 percentage units per year, respectively. Warren et al. (1996) determined that honey mesquite cover on two sites in southern New Mexico increased from 1.5 to $8.9 \%$ and 5.0 to $16.1 \%$, respectively, over 10 years (1982-1992), an increase of 0.7 and 1.1 percentage units per year. In Arizona, Parker and Martin (1952) found that velvet mesquite (Prosopis velutina) cover, when averaged over various grazing treatments, increased from 7 to $17 \%$ in 17 years (1932 to 1949), or 0.6 percentage units per year.

Other shrub species in the west or southwest have exhibited slower rates of cover increases. Smeins and Merrill (1988) found that cover of a mixture of woody species in central Texas increased from 12 to $32 \%$ over 34 years (1949 to 1983), or 0.6 percentage units per year. Smeins et al. (1994) found in central Texas, that Ashe juniper (Juniperus ashii Buchh.) cover increased from 1 to $12 \%$ over 30 years (1955 to 1985 ), or 0.4 percentage units per year. A recent study on 3 sites in Oregon found that increases in western juniper (Juniperus occidentalis spp. occidentalis Hook.) cover over 42 years (1951 to 1994) ranged from 0.1 to 0.2 percentage units per year (Soule and Knapp 1999). These findings are not surprising because Juniperus species have slower growth rates than mesquite (Owens and Ansley 1997).

Differences in reported rates of mesquite cover increases are the results of differences in initial canopy cover, soils, weather, and other factors. However, we can conclude from the data available that long-term increases in mesquite cover rarely exceed 1 percentage unit per year on most sites. In contrast, the 2.2 percentage units per year increase on our untreated area over 20 years was twice that found in the literature. While increases from 1976 to 1990 (1.6 and 0.2 percentage units per year in untreated and root-plowed, respectively) are similar to those of other studies, higher rates of increased cover from 1990 to 1995 (4.1 and 3.7 percentage units per year) seem atypical and suggest either a response to above-normal precipitation or an over-estimate of cover on the 1995 images due to shade cast by mesquite canopies and/or low quality of the images.

Soils on our site are deep clay loams which can annually produce 2,000 to $3,500 \mathrm{Kg} \mathrm{ha}^{-1}$ of herbaceous growth in mesquite-free areas. This productive potential is much higher than on sites described by Archer et al. (1988) in south Texas, Warren et al. (1996) in New Mexico, and Parker and Martin (1952) in Arizona. Normal rainfall on our site is also much greater than that in the New Mexico and Arizona studies, but similar to the study site described by Archer et al. (1988) in south Texas. Our results indicate that, even though the growing season is shorter in this northern portion of the mesquite distribution range, rate of mesquite cover increase appears to be no lower than what other studies have determined for more southern mesquite.

Cattle grazing has been associated with increases in the rate of mesquite encroachment either through reduced competition from the herbaceous community (Archer et al. 1995), or through fecal deposition of mesquite seeds (Kramp et al. 1998). The 
fact that cover increased at a greater rate in both treatment areas after removal of cattle grazing in 1988 cattle grazing did not influence rate of cover increase as much as did precipitation.

As with other woody species, at some high level of cover, mesquite growth may become self-limiting and rate of cover increase may slow. However, there was no indication of this occurring in this study between 1976 and 1995 at cover values as high as 59\%. Ansley et al. (1998) found that growth and leaf area of individual mesquite trees was reduced at $40 \%$ canopy cover when compared to trees at $12 \%$ cover, but effects of these levels of canopy cover on subsequent increases in cover were not determined.

\section{Conclusions}

Statistical inferences regarding mesquite cover responses in this study were obtained from individual macroplots within a specific plant community and may not be applicable to other areas. We believe, however, that trends determined in this study are typical of that found on similar community types in north Texas and assume responsibility for these interpretations.

In conclusion, honey mesquite cover increased significantly $(\mathrm{P} \leq 0.05)$ in both the untreated and root-plow treatments over the 20-year period, but the rate of increase was significantly greater in the untreated area $(2.2$ percentage units per year) than in the root-plow treatment (1.1 percentage units per year). Rate of increase was greater in both treatments during an above normal precipitation period than during a period which had average precipitation. Rates of increase in cover in the untreated area were greater than that found for honey or velvet mesquite in other studies in south Texas, New Mexico or Arizona. This was attributed to greater annual precipitation and more productive soils at our site. All spatial attributes measured (patch density, patch size, patch shape index, nearest neighbor distance) suggested an increase in coalescence of canopies in the untreated site with little recruitment. Conversely, cover changes in the root-plow treatment were the result of recruitment and growth of individual patches, with little coalescence within 20 years after treatment.

\section{Literature Cited}

Ansley, R.J., B.A. Trevino, and P.W. Jacoby. 1998. Intraspecific competition in honey mesquite: leaf and whole plant responses. J. Range Manage. 51:345-352

Archer, S. 1989. Have southern Texas savannas been converted to woodlands in recent history? The American Natur. 134:545-561

Archer, S., C. Scifres, C.R. Bassham, and R. Maggio. 1988. Autogenic succession in a subtropical savanna: conversion of grassland to thorn woodland. Ecol. Monogr. 58: 111-127.

Archer, S., D.S. Schimel, and E.A. Holland. 1995. Mechanisms of shrubland expansion: land use, climate or $\mathrm{CO}_{2}$ ? Climatic Change 29:91-99.

Bartlett, J.R. 1854. Personal narrative of explorations and incidents in Texas, New Mexico, California, Sonora and Chihuahua. D. Appleton \& Co., New York, N.Y.

Buffington, L.C. and C.H. Herbel. 1965. Vegetational changes on a semi-desert grassland range from 1858 to 1963 . Ecol. Monogr. 35:139-164.

Cook, C.W. and J.E.Stubbendieck. 1986. Range research: basic problems and techniques. Society for Range Manage., Denver, Colo.

Daubenmire, R.F. 1959. A canopy coverage method of vegetational analysis. Northw. Sci. 33: 43-64.

ESRI. 1998a. Getting to Know ArcView GIS. Environ. Systems Res. Inst. (ESRI), Inc. Redlands, Calif.

ESRI. 1998b. Working with ArcView Spatial Analyst. Environ. Systems Res. Inst. (ESRI), Inc. Redlands, Calif.

Fisher, C.E., C.H. Meadors, R. Behrenns, E.D. Robison, P.T. Marion, and H.L. Morton. 1959. Control of mesquite on grazing lands. Tex. Agr. Exp. Sta. Bull. 935, College Station, Tex.

Garrison, G.L. and K.C. McDaniel. 1982. New Mexico brush Inventory. N. M. Dept. Agr. Spec. Rep. No. 1., Las Cruces, N.M.

Grover, H.D. and H.B. Musick. 1990. Shrubland encroachment in southern New Mexico, U.S.A.: an analysis of desertification processes in the American southwest. Climatic Change 12:305-330.

Gustafson, E.J. 1998. Quantifying landscape spatial pattern: what is the state of the art?. Ecosystems 1: 143-156.

Hamilton, W.T., L.M. Kitchen, and C.J. Scifres. 1981. Height replacement of selected woody plants following burning or shredding. Tex. Agr. Exp. Sta. Bull. 1361, College Station, Tex.

Hastings, J.R. and R.M. Turner. 1965. The changing mile: an ecological study of vegetation change with time in the lower mile of an arid and semi-arid region. Univ. Ariz. Press, Tucson, Ariz.

Heitschmidt, R.K. and R.D. Schultz. 1985. Effects of drought on a grassland in the northern Rolling Plains of Texas. The Southwestern Natur. 30:319-320.

Humphrey, R.R. 1949. Fire as a means of controlling velvet mesquite, burroweed, and cholla on southern Arizona ranges. J. Range Manage. 2:175-182.
Jacoby, P.W. and R.J. Ansley. 1991. Mesquite: classification, distribution, ecology and control. p 364-376 In: L.F. James, J.O. Evans, M.H. Ralphs, D.R. Child (eds.) Noxious Range Weeds. Westview Press, Boulder, Colo.

Koos, W.M., J.C. Williams, and M.L. Dixon. 1962. Soil survey of Wilbarger County, Texas. USDA-SCS, Soil Survey Series 1959, Number 18, Fort Worth, Tex.

Kramp, B.A., R.J. Ansley, and T.R. Tunnell. 1998. Survival of mesquite seedlings emerging from cattle and wildlife feces in a semiarid grassland. The Southwestern Natur. 43: 300-312.

Martin, S.C. and R.M. Turner. 1977. Vegetation change in the Sonoran desert region, Arizona and Sonora. J. Ariz. Acad. Sci. 12: 59-69.

Marcy, R.B. 1866. Thirty years of army life on the border. Harper and Bros., New York, N.Y.

McGarigal, K. and B.J. Marks. 1995. FRAGSTATS: spatial pattern analysis program for quantifying landscape structure. USDA For. Serv. Pacific Northwest Res. Sta. Gen. Tech. Rep. 351.

Owens, M.K. and R.J. Ansley 1997. Ecophysiology and growth of Ashe and redberry juniper. Chap. 3, p 19-31, In: C.A. Taylor (ed.). Proceedings-1997 Juniper Symposium. Tex. Agr. Exp. Sta. Tech. Rep. 97-1, San Angelo, Tex.

Parker, K.W. and S.C. Martin. 1952. The mesquite problem on southern Arizona ranges. USDA Circ. 908, Washington D.C.

Polly, H.W., H.B. Johnson, and H.S. Mayeux. 1994. Increasing $\mathrm{CO}_{2}$ : comparative responses of the $\mathrm{C} 4$ grass Schizachyrium and grassland invader Prosopis. Ecol. 75:976-988.

Scifres, C.J. 1980. Brush Management Principles and Practices for Texas and the Southwest. Texas A\&M Univ. Press, College Station, Tex.

SCS. 1988. Texas brush inventory. USDASCS, Temple, Tex.

Smeins, F. and L.B. Merrill. 1988. Long-term change in a semi-arid grassland. In: B.B. Amos and F.R. Gehlback (eds.). Edwards Plateau Vegetation-Plant Ecological Studies in Central Texas. Baylor Univ. Press, Waco, Tex.

Smeins, F., M.K. Owens, and S.D. Fuhlendorf. 1994. Biology and ecology of Ashe (blueberry) juniper. p 9-24, In: C.A. Taylor (ed.). Proceedings-Juniper Symposium. Tex. Agr. Exp. Sta. Tech. Rep. 94-2, Sonora, Tex.

Smith, H.N. and C.A. Rechenthin. 1964. Grassland restoration- the Texas brush problem. USDA-SCS, Temple, Tex.

Soule, P.T. and P.A. Knapp. 1999. Western juniper expansion on adjacent disturbed and near relict sites. J. Range Manage. 52:525-533

Warren, A., J. Holechek, and M. Cardenas. 1996. Honey mesquite influences on Chihuahuan desert vegetation. J. Range Manage. 49:46-52.

Wu, X.B., T.L. Thurow, and S.G. Whisenant. 2000. Fragmentation and changes in hydrologic function of tiger bush landscapes, southwest Niger. J. Ecol. 88:790-800. 